\title{
Adapting to Individual Differences (ATID) For Inductive Thinking and Learning Purpose
}

\author{
Nia Rohayati ${ }^{1}$, Deni Darmawan ${ }^{*}, 2$ \\ ${ }^{1}$ Language Education Indonesian Literacy and Regions Department, Galuh University, 46213, Indonesia \\ ${ }^{2}$ Educational Technology and Communication Science Department, Indonesia University of Education, 40154, Indonesia
}

\author{
A R T I C L E I N F O \\ Article history: \\ Received: 02 March, 2020 \\ Accepted: 03 June, 2020 \\ Online: 06 July, 2020
}

\section{Keywords:}

Adapting to individual differences

Inductive thinking

Learning purpose

\begin{abstract}
A B S T R A C T
The research in general aims to develop students' writing skills by applying a model with reader response strategy and visual symbols to promote students' morals. Specifically, this inquiry is expected to describe the acceptability, comparison, impact, strength, and shortcomings, and the model Adapting To Individual Differences (ATID) of Indonesian literature learning to promote writing skills. This research used a quantitative approach to a quasi-experiment design. Nevertheless, a qualitative approach was also used to analyze students' writing. It was concluded that (1) the model of Adapting to Individual Differences (ATID) in Indonesian literature learning was able to promote students' writing skills, (2) the model of Adapting to Individual Differences (ATID) possessed the strength comparatively in quasi-experiment class. (3) the shortcomings of the model where it spent much time as students responded both nonverbally and verbally and guided questions facilitated students to express their responses. (4) the model of Adapting to Individual Differences (ATID) indicated the significant difference to the increasing of students' write skills in the quasi-experiment class And (5) the model of Adapting to Individual Differences (ATID) showed good qualification where the aspect of cognitive, affective, and psychomotor was developed.
\end{abstract}

\section{Introduction}

The teaching of literacy can not be separated from the teaching of the language even though it seems separated based on the basic competencies. In the education of the Indonesian language, the term "language" and "literary" tends to be interpreted separately [1]. The aforementioned tendencies are often led to discordant proposals that the language and literacy should be taught by different teachers. Based on the findings of [2] there are $91.6 \%$ of respondents who gave responses "agreed" that the literary should be separated from a language concerning the autonomy of literary teaching. Several reasons are supporting such separation, including 1) the position of the teaching of literary will be more stable and more focused because it has clear goals and the allocation of sufficient time, 2) the teaching of literacy will be taught by teachers who have a love and a great commitment in literary, 3) The government is expected to provide some special literary's textbooks and its support, 4) the teaching of literacy in schools will be able to achieve the expected goals

\footnotetext{
*Deni Darmawan, Indonesia University of Education, Street of Dr. Setiabudi, 229
} Bandung, 40154, Phone (022)2013163, Email: deni_darmawan@upi.edu and objectives. The tendency on the separation or the unification of the language and literacy motivates writers to conduct research that does not make sense to both of these competencies as a dichotomy. This study put the languages and literacies on an equal footing. Equality is supported by the opinion of [3] who stated that the students' language skills can be developed systematically if the literacy is taught side by side with the language. So both of these competencies become the basis for conducting research. Furthermore, the literature can enhance the students' understanding of the Indonesian language because of the variety of sentences and vocabulary that learned. According to [4] Students will understand the language well through the learning of literacy. However, currently, the portion of basic competence of literacy is very small compared with the portion of teaching the languages; let alone four basic competencies are closely related to language. This is caused by curriculum guidelines applicable at the time (the communicative approach/meaningfulness). Even pointed out the literacy teaching at elementary school is very far from satisfactory because the basic competence can not develop the There are some problems concerning the low quality of learning the language skills, [5] explains that according to 
research conducted by Taufik Ismail, turns out that the writing skills of Indonesian students are the lowest in Asia. Similarly, according to a[6], about the test results of the grade IV elementary school students, Indonesia was ranked as the lowest in East Asia. The average reading test results in some states are as follows: Hong Kong 75.5\%, Singapore 74\%, Thailand $65.1 \%$, Philippines $52.6 \%$, and Indonesia $51.7 \%$ [7]. Furthermore, Semiawan also explained that the results of the study showed that the students in Indonesia was only able to understand $30 \%$ of the reading material and had difficulty answering questions that require reasoning description. The low level of literacy in Indonesia, because there are too many students and scattered in a number of remote islands. In addition, the area is difficult to reach, so the literacy program requires access and equity, which requires time. Besides the culture of each region is different so that literacy learning requires variation and creativity from its educators.

Difficulty in writing experienced by students is caused by the fact that the students are not getting used to being trained to write from the beginning. In a writing exercise, students experienced difficulties because of the difficulty to prepare the first sentence. They are confused about where to start writing and how to open the first sentence in writing. Determining the points of writing is a difficult thing for students. Student's utterances like "I'm confused do not know what I would write." " I have a lot of material/things I want to write, but I do not know how to vote". "Several times I change my mind about the subject I wanted to write but do not get a steady". The remarks indicate that the student is difficult to start writing.

In connection with the statement above, the teaching of writing need to switch from a conventional learning model (which is based on the assumption that "knowledge can be transferred intact from that of the teacher to the student's mind") to the learning modern learning model, namely the model of Adapting To Individual Differences (ATID). This model is based on the assumption that "knowledge is constructed in the minds of students". Following the scope of the problem as has been described above, the key problem of research is formulated as follows: "Is the implementation of the ATID model in learning of Indonesian literacy can improve the writing skills of Indonesian literacy in level VIII junior high school students?". This study aimed to describe the increase in the ability to write Indonesian literacy in the level of VIII junior high school by using the ATID model.

\section{Theoretical Review}

\subsection{Adapting to Individual Differences (ATID) in Language and Literacy Learning}

ATID is a theory of learning to improve Indonesian literacy writing skills. Learning theory developed by [8], explains that strategies and techniques that will be developed in the form of a media print to appreciate the literacy that use non-print media to express the results of the literacy. As noted by [9] who formulated four visual dimensions that can be used to respond to a literacy works, namely (a) graph, consisting of sociogram, maps, cards, diagrams, and calligraphy, (b) Illustration, consisting of poster, photographs, collections, and drawings, (c) film/video, consisting of narrative texts, animations, movies, and special effects, and (d) performing arts, consisting of the tableau, dance, music, and pantomime. The use of visual symbols is an attempt to expand and enrich the interpretation and response toward literacy. Following the research subject which are the elementary school students, for this research, the visual symbols used is limited to sociogram and images.

The ATID model is a personal development learning model that influenced by congenital and external factors. Thus, in lesson planning, it must consider two factors. In this study, the model is applied concerning a verbal response which is owned by the students.

Verbal responses are an important factor in the learning process that can be applied to appreciate the literacy by using words that expressed orally and in writing. In this study, the verbal response in the form of writing is the reader response strategy proposed by [10]. Reader response is a theory or a strategy of contemporary literacy that oriented to the role of readers who interact with literacy at the time the work was assessed. Reader response strategies consists of seven factors, namely: (a) engaging, (b) describing, (c) conceiving, (d) explaining, (e) connecting, (f) interpreting, and (g) judging.

\subsection{Literacy Learning}

Literacy learning is oriented to the visual dimensions which relevant to the reader response, i.e. with the literacy learning theory, basic operations theory, and steps of the learning model of inductive thinking (basic inductive model). The learning model of inductive thinking is put forward by [8] as follows: (a) the formation of concepts (identifying, investigating, and conclusion), (b) the interpretation of data (predict, explain, and testing), and (c) application of the principle (predict, explain, and test).

Literacy learning in this study will be carried out by presenting the subject material about: "The insight into the knowledge of who he is in the family", which described in figure 1.

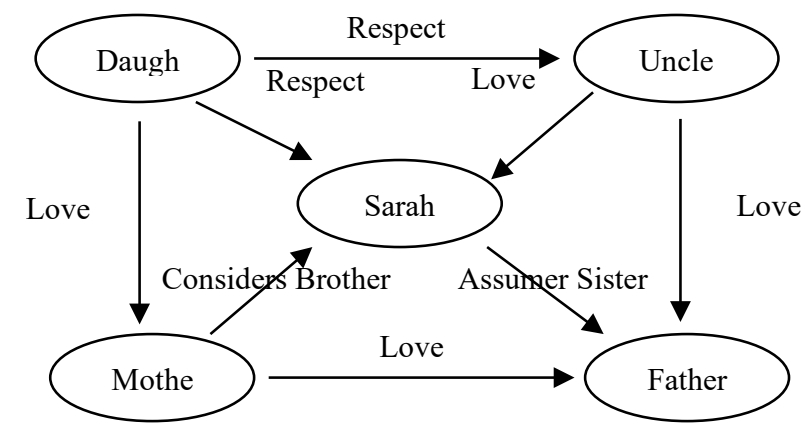

Figure 1: Map material-1 which will be experimented to guide students for develop writing skills of Indonesia literacy using the model of ATID

Based on Figure 1, students are expected to be able to develop the literacy work with the ideas of attitudes and behavior of himself in his family environment. The family map above educates in developing literacy skills with ATID. Thus, all students throughout the archipelago and inland areas in Indonesia certainly have a family. Thus, in improving literacy ability through the ATID model it can be done by all educators in all regions in Indonesia equally.

\section{Research Methodology}

The research methodology for ATID uses a quantitative approach in quasi-experiment [9] to see differences in the ability of students to write Indonesian Literacy. The population of the research is students of junior high school in Tasikmalaya and 
Singaparna town. There are two class sample: one class as a class experiment that learning using ATID, and the other class as a class control that learning using a traditional model.

The technique of data collection is performed using a learning test in the form of questions about the ability to write a literacy in the Indonesian Language. On the other hand, the technique of data analysis uses a t-test to evaluate the average differences outcomes of student learning in writing literacy of the Indonesian Language between experimental class and control class. To get students who have similar achievements and prior learning abilities, the homogeneity of the experimental class and the control class are used in the sampling technique.

\section{Result and Discussion}

The advantage of learning models with ATID can facilitate students in acquiring the ability to write literacy about "Insight knowledge of who he or she was in the family." Table 1 shows the result of the research in the experimental class and control class.

Table 1: The Score of Writing Skills of Indonesian Literacy Pre-Test and PostTest Class Quasi Experiment

\begin{tabular}{|l|l|l|l|}
\hline \multicolumn{5}{|c|}{ The Average Results of Two Evaluator in Class Quasi- } \\
\hline No. & Pre-Test & \multicolumn{1}{|c|}{ Post-Test } & Gain \\
\hline 1 & 75 & 90 & 15 \\
\hline 2 & 72 & 85 & 13 \\
\hline 3 & 75 & 90 & 15 \\
\hline 4 & 72 & 80 & 8 \\
\hline 5 & 75 & 90 & 15 \\
\hline 6 & 68 & 85 & 17 \\
\hline 7 & 65 & 75 & 10 \\
\hline 8 & 65 & 75 & 10 \\
\hline 9 & 65 & 79 & 14 \\
\hline 10 & 63 & 74 & 11 \\
\hline 11 & 59 & 67 & 8 \\
\hline 12 & 61 & 72 & 11 \\
\hline 13 & 59 & 65 & 6 \\
\hline 14 & 65 & 73 & 8 \\
\hline 15 & 55 & 69 & 14 \\
\hline 16 & 55 & 72 & 17 \\
\hline 17 & 65 & 65 & 0 \\
\hline 18 & 49 & 61 & 12 \\
\hline 19 & 50 & 59 & 9 \\
\hline 20 & 50 & 59 & 9 \\
\hline$\Sigma$ & 1263 & 1485 & 222 \\
\hline $\bar{\chi}$ & 63.15 & 74.25 & 11.1 \\
\hline & & 65 & \\
\hline
\end{tabular}

Tabel.1 indicates that the average score of pretest about writing literacy in the experimental class was 63.15 . To realize the student's competence, the teacher has to explain how to bring the students feeling towards the story action that read by students [10]. Besides, teachers should explain how to connect all the elements in the story with the social and cultural life. Competence in identifying the literary works presented by [11]while the religious perspective by[7]. Meanwhile, listening and speaking activities can be conducted in the discussion forum, which discussed the results of reading by all students.

After learning literature by applying the model Atid implemented, the average value of responding turned into 74.25. The average gain between the pre-test and post-test scores was 11.1. It shows that a significant increase in the value of post-test students after learning literature by applying the model ATID does. The following table clearly shows the difference between the pre-test to post-test values obtained in a quasi-experimental class of the capability of writing an Indonesian literacy [12].

Results of further testing in the form table below which shows the results of pre-test and post-test grade control, the ability to write an Indonesia literacy.

Table 2: Score of Writing Skills of Indonesian Literacy

\begin{tabular}{|l|l|l|l|}
\hline \multicolumn{4}{|c|}{ The Average Results of Two Evaluator in Class Control } \\
\hline No. & \multicolumn{1}{|c|}{ Pre-test } & \multicolumn{1}{c|}{ Post-test } & Gain \\
\hline 1 & 80 & 82 & 2 \\
\hline 2 & 79 & 80 & 1 \\
\hline 3 & 75 & 77 & 2 \\
\hline 4 & 72 & 75 & 3 \\
\hline 5 & 72 & 73 & 1 \\
\hline 6 & 72 & 75 & 3 \\
\hline 7 & 75 & 79 & 4 \\
\hline 8 & 69 & 72 & 3 \\
\hline 9 & 69 & 70 & 1 \\
\hline 10 & 65 & 66 & 1 \\
\hline 11 & 61 & 65 & 4 \\
\hline 12 & 69 & 70 & 1 \\
\hline 13 & 55 & 60 & 5 \\
\hline 14 & 55 & 58 & 3 \\
\hline 15 & 59 & 64 & 5 \\
\hline 16 & 59 & 61 & 2 \\
\hline 17 & 61 & 61 & 0 \\
\hline 18 & 59 & 61 & 2 \\
\hline 19 & 59 & 61 & 2 \\
\hline 20 & 50 & 58 & 83 \\
\hline$\Sigma$ & 1315 & 1368 & 2.65 \\
\hline $\bar{\chi}$ & 65.75 & 68.4 & \\
\hline & & & 8 \\
\hline
\end{tabular}

Table 2 above indicates that the average value of pretest responded to stories in the control class is 65.75 . The value increased to 68.4 after students take the post-test with a value gain of 2.65. The average gain between the pre-test and post-test scores was 2.65. It shows that an increase of the value pretest to the value of post-test although the increase is much lower than grade 
students quasi-experimental experience learning by applying the model ATID treatment with students who are not being treated. Because the value signification post-test capability wrote literature students is 0,000 less than the real value of 0.05 , then Ho is rejected. This fact can be seen in the table on the average difference test writing skills literary works Indonesia between the two groups of students are students of a quasi-experimental class and control class as follows [13]. This finding shows the ATID model is very effective in helping improve language literacy in students.

Table 3: Writing Skills Test Results Literacy of Indonesian Students between pre-test and post-test Class Quasi-Experiment

Paired Samples Test

\begin{tabular}{|c|c|c|c|c|c|c|c|c|}
\hline & \multicolumn{5}{|c|}{ Paired Differences } & \multirow[b]{3}{*}{$\mathrm{r} \quad \mathrm{t}$} & \multirow[b]{3}{*}{ df } & \multirow{3}{*}{$\begin{array}{c}\text { Sig. } \\
\text { (2-tailed) }\end{array}$} \\
\hline & \multirow[b]{2}{*}{ Mean } & \multirow{2}{*}{$\begin{array}{l}\text { Std. } \\
\text { Dev }\end{array}$} & \multirow{2}{*}{$\begin{array}{c}\text { Std. } \\
\text { Error } \\
\text { Mean }\end{array}$} & \multicolumn{2}{|c|}{$\begin{array}{l}95 \% \text { Confiden } \\
\text { Interval of the } \\
\text { Difference }\end{array}$} & & & \\
\hline & & & & Lower & Upper & & & \\
\hline $\begin{array}{cc}\text { Pair } & \text { ost test Experiment } \\
1 & \text { Post test Control }\end{array}$ & 5.850 & 5.53719 & 1.2382 & 3.2585 & 8.4415 & 4.725 & 19 & .000 \\
\hline
\end{tabular}

Based on the results of testing the application of learning models ATID above either through an experimental class and control, as well as mapping the topics that have experimented then be analyzed as follows. From the aspect of materials developed maps, classes that are subjected to ATID models further demonstrate the superiority that is, when compared with the acquisition of control class capabilities. This is evident from the difference in mean pre-test / post-test experimental and control classes. The next important thing is inferred ATID models that had been developed before students write short stories. Based on the results of analyzing aspects of clarity, accuracy, interest, inclusiveness, and completeness, all the students' concept is based on individual differences in which includes seven elements of the set (determination of the characterization of short stories that became the focus of the story; the laying of the characters; creativity to color each character or the gist of the story; the use of symbols, and the nature of the schematic in the concept has shown its quality is right, because the average concepts students have demonstrated the clarity, precision, interest, inclusiveness, and completeness well, imagination, and schematic. These findings have implemented the opinion of [11], which suggests that teachers should explain how to engage the students to feel the characters were read by the students and how to connect all the elements in the story with the social and cultural life in identifying literature [14]. Through the process of and findings in his research, particularly efforts to enable the students for learning Indonesian, it is expected to answer the concerns of the opinion from [15] which states that students are still less skilled Indonesian language.

During the process of revision of the test in the form of experimental activities carried out during the study, indirect stages in this study require students to keep repeating about the ability of ideas, story ideas, and contents of the map material have experimented. This finding is consistent with the policy of the [16], one of the specific goals of learning the use of language is that students should be able to express ideas, opinions, knowledge in writing, and has a penchant for writing. To express ideas, opinions, and knowledge, students need to be given training on an ongoing basis.

Students' attitudes towards writing activities positively, because students perceive, that after reading activities should be followed by a short story writing activity is an activity that first time they have experienced, and generally students always scored less satisfactory as long as they do learning activities during this writing. Students' interest in learning writing looked on: students are always trying to do the tasks write well; students have never submitted responses to literature critically; students feel impressed, when analyzing the literature Indonesia / stories should be linked to the values of life in the real world: students feel happy if the reading of literary works continued with analyzing the literature, and, students feel happy if his writings published in the magazine wall. From these findings, it has put role models ATID Indonesian teachers who can make skillful use of Indonesian students in all its functions, especially the function of communication. This finding is consistent with the opinion of [17] states that "To teach literature Correctly is to emphasized the aesthetic stance and to emphasize the efferent." That is, students are not only able to identify what is contained in literary works such as background, character, and characterization, as well as the storyline, but they were also able to identify what is on the outside of the literary works such as the author's intention, symbolism, storytelling and so forth.

Besides, students should not only be trained in listening skills, speaking, reading, and writing, but are trained to think and reason in an orderly manner in the Indonesian language. [18] describes the relationship of writing to think as one aspect of language skills. Nickerson said that frozen speech or utterance is another name for the author. Writing a valuable contribution to civilization, namely an enduring record. Note perennial accelerate the accumulation of knowledge [19].

The externally within the meaning of the teacher's role when it illustrates the material into a story, among others, played by the students then students will be more motivated to understand it. This finding is supported by the opinion of [20] illustrates if there are students who are not able to express a new story read verbally, but he was unable to explain what happened in a story in creating the image, the teacher should receive a response so. Thus, students are motivated to learn to write short stories, because teachers create an atmosphere of fun teaching; because teachers provide a model of analysis of literary work that is attractive and easy [21].

\section{Conclusion and Recommendation}

\subsection{Conclusion}

Based on analyzing and testing through the research that has been done the level of ability to write short stories before and after the model Adapting to Individual Differences (ATID) eighthgrade students at two public junior high school in Tasikmalaya, shows that there increasing ability Indonesia wrote literature student after the student gets treatment the ATID models [22].

From the findings and discussion, the conclusions are real that the model of ATID in Indonesian literature learning was able to promote students' writing skills. The model of ATID possessed strength comparatively in the quasi-experiment class. Then the shortcomings of the model were it spent much time as students responded both non verbally and verbally and guided questions 
facilitated students to express their responses. The model of ATID indicated the significant difference to the increasing of students' writing skills in the quasi-experiment class and this model showed good qualification where the aspect of cognitive, affective, and psychomotor was developed [23].

\subsection{Recommendation}

Based on these results it can be recommended that with the application of this ATID very impressed with the students' learning model with a model to write short stories with the ATID model [12]. For teachers should be able to pay attention to aspects of the utilization of the model both in terms of ease of understanding of learning, in terms of function chart and coloring creativity and depiction of the emblem in sociogram, in terms of usability order of ideas in concept, in terms of the psychology of learning [24], as well as in terms of the sustainability of the use of models ATID. Another recommendation is expected that teachers should continue to support the students' ability to write literary works to cultivate the application of this model for future learning.

\section{Conflict of Interest}

The authors declare no conflict of interest.

\section{Acknowledgment}

The author would like to express gratitude to the Ministry of Research and Technology of Indonesia that has provided research grants, and to the leadership of the Galuh University who has permitted to complete this research to provide benefits in the world of education.

\section{References}

[1] H. Yu, J. An, J. Yoon, H. Kim, and Y. Ko, "Simple methods to overcome the limitations of general word representations in natural language processing tasks I," Comput. Speech Lang., 59, 91-113, 2020, DOI: 10.1016/j.csl.2019.04.009.

[2] K. A. Harras, "Problems of Literature Teaching Problems: Language and Literature," J. Lang. Educ. Lit. Teaching., 3 Teaching Language, 2003.

[3] R. dan M. N. L. Carter, "Teaching Literature," New York Longman, Inc., 1991.

[4] M. R. Zughoul, "English Department in the Third World Universities: Language, Linguistic, or Literature," English Teach. Forum, 4, 2006.

[5] A. Imran, "The Lowest Writing Skills of Indonesian Students in Asia," People's Mind, 26, October 2000.

[6] W. B. Report, "Writing skill in Indonesia," Annu. Report Lit. The Asia Pacific, 1998.

[7] Semiawan., "Rhetoric in Writing," Jakarta: Depdikbud Dikti PPLPTK, 2003.

[8] David Hunt and Schroeder, "Writing Skill in Language Literate," Lang. Literature, 7 Oct 2019.

[9] W.R.B. Gall, Meredith D., J.P. Gall, "Educational Research: An Introduction," NY Pearson Educ. Inc., 7, 2003.

[10] C. Liu, R. Wang, L. Li, G. Ding, J. Yang, and P. Li, "E ff acts of encoding modes on the memory of naturalistic events," 53, August 2019, 2020, DOI: 10.1016/j.jneuroling.2019.100863.

[11] R. W. \& J. D. M. Beach, "Teaching Literature in the Secondary School," New York Harcourt Brace Jovanovich, Inc., 1991.

[12] M. Michel, J. Kormos, T. Brunfaut, and M. Ratajczak, "Journal of Second Language Writing The role of working memory in young second language learners' written performances," J. Second Lang. Writ., 45, May 2018, 3145, 2019, DOI: 10.1016/j.jslw.2019.03.002.

[13] M. K. Tåqvist, "Journal of Second Language Writing ' A wise decision ': Pre-Modi fi cation of discourse-organizing nouns in L2 writing," J. Second Lang. Writ., 41, June, 14-26, 2018, DOI: 10.1016/j.jslw.2018.05.003.

[14] M. Yoyo, "The Effectiveness of the Teaching Model on Reader Responses in Teaching Poetry Study; Experimental Study on Students of Indonesian
Language and Literature Education Department FPBS Bandung,” Diss. Bandung UPI PPS., 1998/1999, 2000.

[15] J. Badudu, "This is the correct Indonesian IV," Jakarta: Gramedia Pustaka Utama., 2015.

[16] D. of E. and Culture., "Socialization of Indonesian Language Learning," Jakarta: Balai Pustaka, 2018.

[17] L.M. Rosenblatt, "The Reader, the Text, the Poem: The Transactional Theory of the Literary Work," Illinois South. Illinois Univ. Press., 1978.

[18] B.K. Owusu and H. Burianová, "Transcranial direct current stimulation improves novel word recall in healthy adults," J. Neurolinguistics, 53 no. August 2019, p. 100862, 2020, DOI: 10.1016/j.jneuroling.2019.100862.

[19] D. Darmawan, Y. Ruyadi, W. J. Abdu, and A. Hufad, "Efforts to know the rate at which students analyze and synthesize information in science and social science disciplines: A multidisciplinary bio-communication study," Online J. Biol. Sci., 17(3), 2017, DOI: 10.3844/ojbsci.2017.226.231.

[20] A.C. Purves, "How Porcupines Make Love 11: Teaching a ResponseCentered Literature Curriculum," New York Longman Group, Ltd., 1990.

[21] K.D. Njikeh, "The Mentally Offset Human and the Society," Open J. Psychiatry, 06(02), 188-190, 2016, DOI: 10.4236/ojpsych.2016.62022.

[22] R. Tanaka, A. Ozeki, S. Kato, and A. Lee, "Computer Speech \& Language Context and knowledge aware conversational model and system combination for grounded response generation," Comput. Speech Lang., 62, p. 101070,2020 , DOI: $10.1016 /$ j.csl.2020.101070.

[23] L. Nuryanti, D. Darmawan, and A. Hufad, "The Implementation Model of Character Building in Curriculum 2013 Through The Scout Movement as A Required Extracurricular in Primary And Secondary Education," 5 (1), 361$367,2020$.

[24] S. Gosselke, M. Horne, K. J. Br, Y. Shtyrov, and M. Roll, "Neural processing of morphosyntactic tonal cues in second-language learners," 45, 2018, doi: 10.1016/j.jneuroling.2017.09.001. 